\title{
In vivo antimalarial effect of Ananas comosus (L) Merr (Bromeliaceae) fruit peel, and gas chromatography-mass spectroscopy profiling: A possible role for polyunsaturated fatty acid
}

\author{
Philip F Uzor*, Blessing U Ishiwu*, Ngozi J Nwodo \\ Department of Pharmaceutical and Medicinal Chemistry, University of Nigeria, Nsukka 410001, Enugu State, Nigeria \\ *For correspondence: Email: philip.uzor@unn.edu.ng; blessingugonne@gmail.com; Tel: +234-703 4484754 (BUI), +234- \\ 8037008294 (PFU)
}

Sent for review: 5 October 2018

Revised accepted: 18 December 2019

\begin{abstract}
Purpose: To evaluate the antimalarial effect of Ananas comosus extract and fractions and also to identify the likely bioactive compounds.

Method: The fruit peel of the plant was extracted with methanol, and the extract successively fractionated with $n$-hexane, dichloromethane, ethyl acetate, methanol and water. The $n$-hexane fraction was further subjected to vacuum liquid chromatography to afford four sub-fractions, one of which was also analyzed using gas chromatography-mass spectroscopy (GC-MS). Plasmodium berghei-infected mice were treated orally with three doses $(100,200$ and $400 \mathrm{mg} / \mathrm{kg}$ ) of the plant extract and a single dose $(200 \mathrm{mg} / \mathrm{kg})$ of each of the fractions and sub-fractions in a curative antimalarial model using artemisinin combination therapy $(A C T)$ as the reference drug.

Results: The extract exhibited significant $(p<0.001)$ non-dose dependent parasitemia inhibitory activity in the range of 44.84 to $76.09 \%$. All fractions displayed inhibitory effect $(p<0.001)$ in the range of 46.44 to $87.58 \%$ with the dichloromethane fraction displaying the highest effect $(87.58 \%)$. The subfractions exhibited significant inhibitory effect $(p<0.001)$ in the range of 84.14 to $92.54 \%$. The ACT produced significant $(p<0.001)$ inhibitory effect of $83.92 \%$. GC-MS analysis revealed the presence of 17 bioactive compounds, the most abundant of which were linoleic acid and palmitic acid.

Conclusion: A. comosus displays strong antimalarial activity which supports the folkloric use of the plant for malarial treatment. A polyunsaturated fatty acid (linoleic acid) was the most abundant phytoconstituent identified.
\end{abstract}

Keywords: Ananas comosus, Antimalarial, Malaria, Pineapple, Plasmodium beighei

This is an Open Access article that uses a fund-ing model which does not charge readers or their institutions for access and distributed under the terms of the Creative Commons Attribution License (http://creativecommons.org/licenses/by/4.0) and the Budapest Open Access Initiative (http://www.budapestopenaccessinitiative.org/read), which permit unrestricted use, distribution, and reproduction in any medium, provided the original work is properly credited.

Tropical Journal of Pharmaceutical Research is indexed by Science Citation Index (SciSearch), Scopus, International Pharmaceutical Abstract, Chemical Abstracts, Embase, Index Copernicus, EBSCO, African Index Medicus, JournalSeek, Journal Citation Reports/Science Edition, Directory of Open Access Journals (DOAJ), African Journal Online, Bioline International, Open-J-Gate and Pharmacy Abstracts

\section{INTRODUCTION}

Malaria is a parasitic disease caused by the Plasmodium species which is associated with significant mortality and morbidity especially in the tropical and subtropical regions of the world [1]. Presently, the first line of treatment of the disease is artemisinin-based combination therapy (ACT). Unfortunately, resistance to ACT has been reported [2]. Therefore, there is urgent quest for novel antimalarial agents particularly 
from medicinal plants which are the sources of the two important antimalarial drugs, quinine and artemisinin.

Ananas comosus (L.) Merr (pineapple) is a perennial plant belonging to the family Bromeliaceae. The plant juice is quite nutritious and consumed globally. Pineapple fruits, peels and fruit infusions contain numerous phytoconstituents including bromelain, polyphenols and alkaloids [3-5]. Apart from its nutritional uses, the plant is used in traditional medicines for various indications, among which include anthelmintic, hiccough, hemorrhoids, constipation, diuretic, laxative, gastric irritability, jaundice, edema, venereal diseases, typhoid fever, strangury, sinusitis, throat problem, toothache, analgesics and diabetes [6]. In addition, $A$. comosus is used in the folkloric treatment of malaria in many countries [7-11]. The antiplasmodial activity of the plant has also been reported in vitro [12]. However, the traditional claim for the antimalarial activity requires further investigation in animal models.

Based on the foregoing, the present study was therefore designed to experimentally investigate the antimalarial effect of $A$. comosus fruit peel in mice. The bioactive constituents of the plant were also explored.

\section{EXPERIMENTAL}

\section{Plant materials}

Fresh fruits of $A$. comosus were collected in April, 2018 from Nsukka town, Enugu State, Nigeria. The specimen was identified by Mr. F. Nwafor, a botanist at the Department of Pharmacognosy and Environmental Medicines, University of Nigeria, Nsukka and deposited in the herbarium of the same department with voucher number PCG/UNN/0023. The plants materials were washed in running water and the peels were obtained by peeling the fruit skins with a knife. The peels were dried in the oven at a temperature of $40^{\circ} \mathrm{C}$. The dry plant material was ground into fine powder and kept in the refrigerator prior to use.

\section{Extraction and fractionation of plant material}

The powdered plant material $(500 \mathrm{~g})$ was macerated in $2.5 \mathrm{~L}$ of $95 \%$ methanol for $72 \mathrm{~h}$ at room temperature $\left(28 \pm 2{ }^{\circ} \mathrm{C}\right)$ with intermittent shaking. The mixture was filtered first through a muslin then followed by filtration through a filter paper (Whatman ${ }^{\circledR}$ Grade 42). The filtrate was evaporated using a rotary evaporator at $40{ }^{\circ} \mathrm{C}$ under reduced pressure to afford the crude extract coded as ACE. The extract (ACE) $(80 \mathrm{~g})$ was further subjected to fractionation by dissolving it successively in $n$-hexane, ethyl acetate, methanol and water. For each solvent, the mixture was filtered and the filtrate concentrated while the residue was dissolved in the next solvent of higher polarity as listed above. This procedure afforded the respective fractions coded as ACH (for $n$-hexane), ACD (for dichloromethane), ACEA (for ethyl acetate), ACM (for methanol) and ACW (for water) fractions. Based on the extractive yield, results of bioactivity assay and trial TLC, the $n$-hexane fraction $(\mathrm{ACH})$ was fractionated on a silica gel vacuum liquid chromatography (VLC) column (70-230 mesh, $500 \mathrm{~g}, 20 \times 6 \mathrm{~cm})$ using gradient elution of $n$-hexane and acetone (volume ratio of 3:2, 1:1, 7:3, 1:4, each $500 \mathrm{~mL}$ ) to afford four (4) sub-fractions coded as $\mathrm{ACH} 1, \mathrm{ACH} 2, \mathrm{ACH} 3$ and $\mathrm{ACH} 4$ respectively.

\section{Animals}

The animals used for the study were albino mice of either sexes which weigh between 20 to $25 \mathrm{~g}$. The animals were obtained from the Faculty of Veterinary Medicine, University of Nigeria, Nsukka. They were allowed ad libitum access to water and feed. They received humane care throughout the experimental period in accordance with the approved protocols (FVUNN.IACUC.2019.0816) of the University of Nigeria Ethical Committee on the Care and Use of Laboratory Animals and the guidelines of the National Research Council [13].

\section{Parasite inoculation}

The donor mouse infected with $P$. berghei was obtained from the animal farm of the Faculty of Veterinary Medicine, University of Nigeria, Nsukka. Inoculum was prepared by drawing blood from the donor mouse and diluting it in Alsever's solution to make a suspension containing about $1 \times 10^{7}$ infected red blood cells (RBC) in every $0.2 \mathrm{~mL}$ suspension.

\section{Curative antimalarial test (Rane's test)}

Curative test model was used for the antimalarial study [14]. On Day 0, the standard inoculum $(0.2$ $\mathrm{mL}$ ) of $1 \times 10^{7}$ infected RBC was inoculated intraperitoneally in mice. Seventy-two hours (72 h) later (Day 3), 70 mice were randomly segregated into 14 groups of five (5) mice and dosed (p.o) once daily for five days (Day 3 to Day 7). Mice in groups 1-3 received 100, 200 and $400 \mathrm{mg} / \mathrm{kg}$ of the extract ACE, groups $4-12$ received $200 \mathrm{mg} / \mathrm{kg}$ each of the fractions/subfractions, $\mathrm{ACH}, \mathrm{ACD}, \mathrm{ACE}, \mathrm{ACM}, \mathrm{ACW}, \mathrm{ACH} 1$, 
$\mathrm{ACH} 2, \mathrm{ACH} 3$ and $\mathrm{ACH} 4$ respectively, group 13 received the standard drug(ACT) while group 14 (Control group) was untreated (infected but received vehicle only). Thin blood film was prepared from the tail of each mouse on Day 3 (before treatment) and Day 8 (one day after the last dose of drug administration) and stained using Geimsa stain in order to monitor parasitemia level. Three stained slides were prepared for each mouse and examined under a microscope with an oil immersion nosepiece of $100 \times$ magnification. The following formula was used to calculate the average parasitemia from three different fields on each slide [15].

Parasitemia $(\%)=($ number of parasitized RBC) $/$ (total number of RBC) $\times 100$

\section{Mean survival time (MST) determination}

Each mouse was observed daily for the determination of the survival time. For each group of mice, MST was determined by calculating the average survival time (days) of mice from Day 0 to Day 29.

\section{Determination of packed cell volume (PCV)}

On Day 8 , the PCV of the mice that received the extract (groups 1-3), as well as ACT (group 13), and the vehicle (group 14) was determined using a Micro-Hematocrit Reader [15]. The animals were sacrificed by ether inhalation.

\section{GC-MS analysis}

The GC-MS analysis of one of the $n$-hexane subfractions (ACH3) was done as previously described [16] using a gas chromatograph equipment that was coupled to a mass selective detector (GCMS-QP2010SE Shimadzu, Japan). The $n$-hexane fraction was chosen for GC-MS analysis as it was the most volatile fraction (thus most suitable for GC-MS analysis). The subfraction of $n$-hexane $(\mathrm{ACH} 3)$ was relatively the most abundant subfraction and also produced a significant $(p<0.001)$ parasitemia reduction. A solution of the sample $(2 \mathrm{mg})$ was made in hexane/acetone mixture, centrifuged at $3000 \mathrm{rpm}$ for $15 \mathrm{~min}$ and the supernatant concentrated to dryness using a rotary evaporator. This was reconstituted with methanol. A sample solution (1 $\mu \mathrm{L})$ was injected for GC-MS analysis in pulsed split mode. The injector and interface were operated at 250 and $270{ }^{\circ} \mathrm{C}$ respectively. The carrier gas was helium with a flow rate of $1.0 \mathrm{~mL} / \mathrm{min}$. Detection by the mass spectrometer was performed in the electron impact (EI) positive mode utilizing high energy electrons
$(70 \mathrm{eV})$. The analysis was repeated three times. Identification of peak was done by matching their mass spectra and retention indices with those on the NIST 11 and Wiley 8 GC-MS data bases.

\section{Statistical analysis}

The statistical package (SPSS version 21.0 USA) was used for data analysis. The results were expressed as mean \pm standard error of mean (SEM). Difference between means was determined by One-Way Analysis of Variance (ANOVA) followed by Dunnet's post hoc test. Values of $p<0.05$ were considered significant.

\section{RESULTS}

\section{Antimalarial activity}

The data from the antimalarial study (Table 1) revealed that the extract (ACE) produced a significant $(p<0.001)$ inhibition of parasitemia in the infected mice in a non-dose dependent manner. The lowest dose of $100 \mathrm{mg} / \mathrm{kg}$ produced better effect $(76.09 \%$ inhibition) than the highest dose of $400 \mathrm{mg} / \mathrm{kg}(44.84 \%)$. All the fractions produced significant $(p<0.001)$ inhibition of parasitemia. The ACD produced the highest inhibitory effect $(87.58 \%)$, followed by ACEA $(85.26 \%)$, ACM $(81.26 \%)$ and $\mathrm{ACH}(79.91 \%)$ while ACW produced the least effect (46.44\%). All the sub-fractions $(\mathrm{ACH} 1$ to $\mathrm{ACH} 4)$ also produced significant inhibition of parasitemia $(p<$ 0.001 ) in the range of 84.14 to $92.54 \%$, with the $\mathrm{ACH} 2$ showing the highest effect $(92.54 \%)$. The results of the sub-fractions $(84.14-92.54 \%, p<$ 0.001 ) were better than that of the standard drug (ACT) which produced $83.42 \%(p<0.001)$ inhibitory effect.

\section{Mean survival time (MST)}

The data show that the ACH4 significantly $(p<$ $0.5)$ prolonged the MST of the infected mice (Table 1). The extract, fractions and the other sub-fractions also exhibited moderate prolongation of the survival time.

\section{Results of packed cell volume (PCV)}

Results of PCV (Table 2) show that the PCV of the mice was lowered on Day 3 (relative to Day $0)$ due to infection by the malaria parasite. The plant extract, however, produced a significant ( $p$ $<0.001$ ) improvement in the PCV of the mice in a non-dose dependent manner. The standard drug (ACT) also caused a significant increase in the PCV. 
Table 1: Effect of $A$. comosus extract and fractions on parasitemia level and MST of the mice in the curative antimalarial model

\begin{tabular}{|c|c|c|c|c|c|}
\hline Group & Treatment & $\begin{array}{c}\text { Parasitemia } \\
\text { (\%, Day 3) }\end{array}$ & $\begin{array}{c}\text { Parasitemia } \\
(\%, \text { Day 8) }\end{array}$ & Inhibition (\%) & $\begin{array}{c}\text { Mean } \\
\text { survival time } \\
\text { (days) }\end{array}$ \\
\hline 1 & $\begin{array}{l}\text { (ACE) } \\
(100 \mathrm{mg} / \mathrm{kg})\end{array}$ & $46.0 \pm 3.56$ & $11.0 \pm 3.49$ & 76.09 & $24.5 \pm 3.50$ \\
\hline 2 & $\begin{array}{l}\text { (ACE) } \\
(200 \mathrm{mg} / \mathrm{kg})\end{array}$ & $38.2 \pm 4.43$ & $9.6 \pm 1.72^{n \prime}$ & 74.87 & $14.6 \pm 4.21$ \\
\hline 3 & $\begin{array}{l}\text { (ACE) } \\
(400 \mathrm{mg} / \mathrm{kg})\end{array}$ & $36.8 \pm 3.33$ & $20.3 \pm 4.87^{\star x \times}$ & 44.84 & $16.0 \pm 2.24$ \\
\hline 4 & $\begin{array}{l}(\mathrm{ACH}) \\
(200 \mathrm{mg})\end{array}$ & $42.8 \pm 5.34$ & $8.6 \pm 2.42 \ldots$ & 79.91 & $19.6 \pm 5.18$ \\
\hline 5 & $\begin{array}{l}(A C D) \\
(200 \mathrm{mg} / \mathrm{kg})\end{array}$ & $44.3 \pm 3.79$ & $5.5 \pm 1.04^{\pi \pi x}$ & 87.58 & $22.3 \pm 5.75$ \\
\hline 6 & $\begin{array}{l}\text { (ACEA) } \\
(200 \mathrm{mg} / \mathrm{kg})\end{array}$ & $50.2 \pm 2.92$ & $7.4 \pm 1.12^{\approx \pi x}$ & 85.26 & $18.0 \pm 6.12$ \\
\hline 7 & $\begin{array}{l}(\mathrm{ACM}) \\
(200 \mathrm{mg} / \mathrm{kg})\end{array}$ & $52.3 \pm 2.06$ & $9.8 \pm 1.84 \ldots$ & 81.26 & $21.0 \pm 4.04$ \\
\hline 8 & $\begin{array}{l}(A C W) \\
(200 \mathrm{mg} / \mathrm{kg})\end{array}$ & $32.3 \pm 5.02$ & $17.3 \pm 1.31^{\star \times x}$ & 46.44 & $11.3 \pm 2.75$ \\
\hline 9 & $\begin{array}{l}(\mathrm{ACH} 1) \\
(200 \mathrm{mg} / \mathrm{kg})\end{array}$ & $57.6 \pm 3.08$ & $7.2 \pm 1.24 \cdots$ & 87.50 & $23.2 \pm 4.80$ \\
\hline 10 & $\begin{array}{l}(\mathrm{ACH} 2) \\
(200 \mathrm{mg} / \mathrm{kg})\end{array}$ & $53.6 \pm 1.38$ & $4.0 \pm 0.84 \cdots$ & 92.54 & $15.6 \pm 5.38$ \\
\hline 11 & $\begin{array}{l}(\mathrm{ACH} 3) \\
(200 \mathrm{mg} / \mathrm{kg})\end{array}$ & $45.4 \pm 4.28$ & $7.2 \pm 2.08^{\star \pi x}$ & 84.14 & $24.4 \pm 3.60$ \\
\hline 12 & $\begin{array}{l}(\mathrm{ACH} 4) \\
(200 \mathrm{mg} / \mathrm{kg})\end{array}$ & $47.6 \pm 5.85$ & $4.8 \pm 1.24 \ldots$ & 89.92 & $28.1 \pm 0.01$ \\
\hline 13 & $\begin{array}{l}\text { (ACT ) } \\
(7 \mathrm{mg} / \mathrm{kg})\end{array}$ & $38.6 \pm 2.54$ & $6.4 \pm 0.93^{\star \pi x}$ & 83.42 & $28.0 \pm 0.00^{\pi}$ \\
\hline 14 & (Control) & $44.4 \pm 3.97$ & $69.0 \pm 1.05$ & -55.41 & $10.8 \pm 1.17$ \\
\hline
\end{tabular}

Table 2: The effect of $A$. comosus extract on PCV of mice

\begin{tabular}{|c|c|c|c|c|}
\hline Parameter & $\begin{array}{c}\text { PCV } \\
\text { (Day 0) }\end{array}$ & $\begin{array}{c}\text { PCV } \\
\text { (Day 3) }\end{array}$ & $\begin{array}{c}\text { PCV } \\
\text { (Day 8) }\end{array}$ & $\begin{array}{c}\text { Change in PCV } \\
(\% \text {, Days } 3 \text { and } 8)\end{array}$ \\
\hline ACE $100 \mathrm{mg} / \mathrm{kg}$ & $39.5 \pm 0.65$ & $28.0 \pm 1.83$ & $38.3 \pm 0.85$ & 26.89 \\
\hline ACE $200 \mathrm{mg} / \mathrm{kg}$ & $40.2 \pm 1.20$ & $27.8 \pm 1.74$ & $38.0 \pm 1.05$ & 36.69 \\
\hline ACE $400 \mathrm{mg} / \mathrm{kg}$ & $41.8 \pm 0.85$ & $29.3 \pm 2.06$ & $40.0 \pm 0.41$ & 36.51 \\
\hline$(\mathrm{ACT}) 7 \mathrm{mg} / \mathrm{kg}$ & $40.2 \pm 0.49$ & $31.2 \pm 0.86$ & $38.4 \pm 0.68^{n-}$ & 18.75 \\
\hline Control & $41.0 \pm 0.55$ & $31.6 \pm 0.81$ & $25.6 \pm 0.93$ & -18.99 \\
\hline
\end{tabular}

\section{Phytochemical constituents}

Results of GC-MS analysis showed that 17 compounds were detected (Table 3; Figure 1). Based on their peak area, linoleic acid (peak area of $59.68 \%$, retention time, $\mathrm{RT},=17.320$ min) was the most abundant compound, followed by palmitic acid ( $n$-hexadecanoic acid, peak area of $33.18 \%$, RT = $16.072 \mathrm{~min}$ ). These two compounds altogether make up to $92.86 \%$ of the sample $(\mathrm{ACH} 3)$ composition. The constituents which make up the remaining $7.14 \%$ of the sample include other fatty acids (such as oleic acid, stearic acid), esters, ketones, aldehydes, alcohols and hydrocarbons.

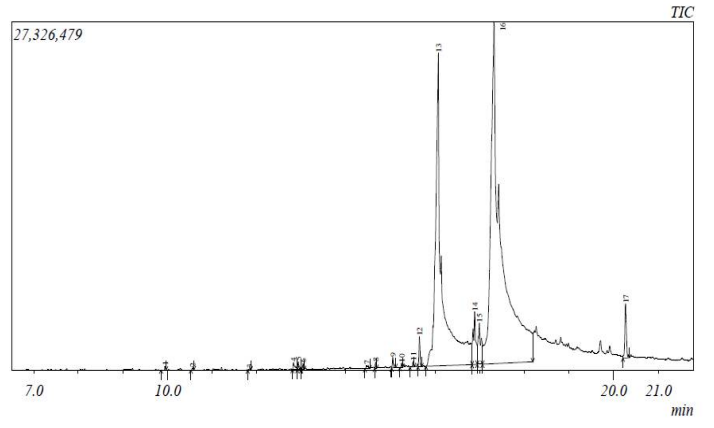

Figure 1: GC-MS chromatogram of the $n$-hexane subfraction of $A$. comosus 
Table 3: Chemical composition of $n$-hexane subfraction of $A$. comosus

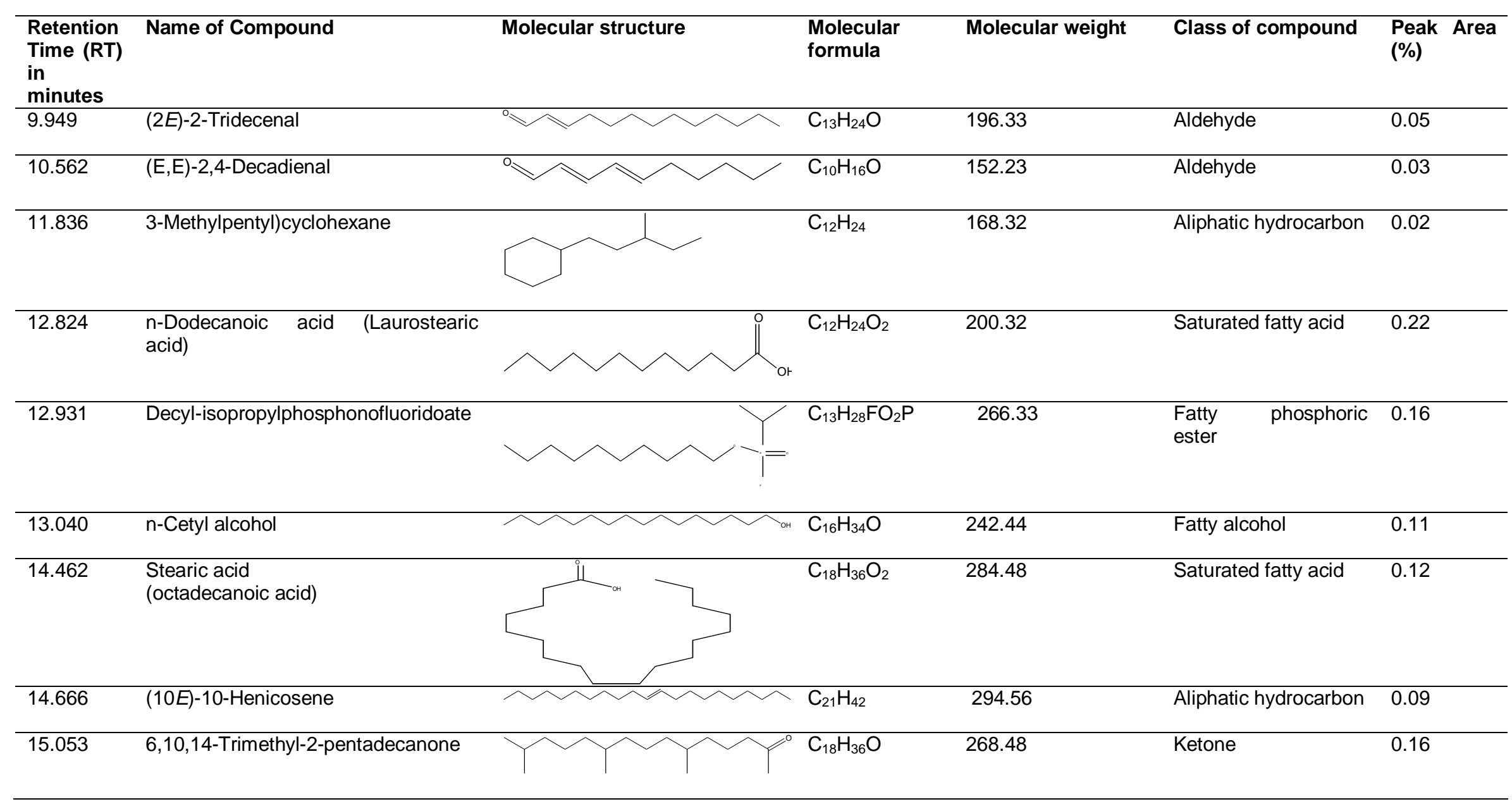


Table 3: Chemical composition of $n$-hexane subfraction of $A$. comosus (continued)

\begin{tabular}{|c|c|c|c|c|c|c|}
\hline $\begin{array}{l}\text { Retention } \\
\text { Time (RT) in } \\
\text { minutes }\end{array}$ & Name of Compound & Molecular structure & $\begin{array}{l}\text { Molecular } \\
\text { formula }\end{array}$ & Molecular weight & Class of compound & $\begin{array}{l}\text { Peak Area } \\
(\%)\end{array}$ \\
\hline 15.251 & Phthalic acid, butyl undecyl ester & & $\mathrm{C}_{23} \mathrm{H}_{36} \mathrm{O}_{4}$ & 276.53 & Fatty ester & 0.06 \\
\hline 15.512 & 2-Hydroxycyclopentadecanone & & $\mathrm{C}_{15} \mathrm{H}_{28} \mathrm{O}_{2}$ & 240.21 & Ketone & 0.12 \\
\hline 15.650 & Palmitic acid, methyl ester & & $\mathrm{C}_{17} \mathrm{H}_{34} \mathrm{O}_{2}$ & 270.45 & Fatty ester & 0.44 \\
\hline 16.072 & n-Hexadecanoic acid (Palmitic acid) & & $\mathrm{C}_{16} \mathrm{H}_{32} \mathrm{O}_{2}$ & 256.00 & Saturated fatty acid & 33.18 \\
\hline 16.887 & $\begin{array}{l}\text { Methyl cis-6-octadecenoate } \\
\text { (Methyl petroselinate) }\end{array}$ & & $\mathrm{C}_{19} \mathrm{H}_{36} \mathrm{O}_{2}$ & 296.49 & Fatty ester & 2.28 \\
\hline 16.991 & cis-Oleic Acid & & $\mathrm{C}_{18} \mathrm{H}_{34} \mathrm{O}_{2}$ & 282.26 & Unsaturated fatty acid & 1.91 \\
\hline 17.320 & $\begin{array}{l}\text { (Z,Z)-9,12-Octadecadienoic } \quad \text { acid } \\
\text { (Linoleic acid) }\end{array}$ & & $\mathrm{C}_{18} \mathrm{H}_{32} \mathrm{O}_{2}$ & 280.45 & $\begin{array}{l}\text { Polyunsaturated fatty } \\
\text { acid (PUFA) }\end{array}$ & 59.68 \\
\hline 20.275 & Bis(2-ethylhexyl) phthalate & & $\mathrm{C}_{24} \mathrm{H}_{38} \mathrm{O}_{4}$ & 390.28 & Fatty ester & 1.35 \\
\hline
\end{tabular}




\section{DISCUSSION}

The current work evaluated the malaria curative effect of $A$. comosus peel in mice. Curative test using $P$. berghei in mouse model is a widely accepted antimalarial evaluation model [17]. The extract was fractionated and one of the active fractions, the $n$-hexane fraction, further partially purified. The $n$-hexane fraction was chosen for further analysis as it is one of the fractions that gave high level of parasitemia inhibition and also the yield (data not shown) was higher than others.

The results showed that the extract and all its fractions and sub-fractions exhibited significant $(p<0.05)$ inhibition of parasitemia. It was also observed that as the extract was purified further, the level of parasitemia inhibition increased; such that the highest level of inhibition for the extract, fractions and subfractions were 76.09, 87.58 and $92.54 \%$ respectively. The parasite inhibitory effect of the subfraction $(92.54 \%)$ was better than that of the reference drug (83.42\%). One of the subfractions also prolonged the survival time of the infected mice. It has been reported that antimalarial test samples that show over $30 \%$ suppressive effect on parasitemia $[18,19]$ or that can prolong the MST of the infected animals [19] are often considered effective antimalarial agent. Therefore, the results from the present study show strong indications that $A$. comosus possesses antimalarial activity which, interestingly, persisted as the extract was further purified.

These findings support the wide use of $A$. comosus fruit or peel in various communities for the treatment of malaria [7-11]. According to the classification of antimalarial activity by Deharo et al [20], the extract and fractions showed very good antiplasmodial activity. This antimalarial activity was further supported by the results of PCV which showed that the extract caused significant increase in this hematological parameter. This also suggests that the plant plays a role in reversing anemic signs induced by the parasite.

The GC-MS analysis was done to explore the likely bioactive principles of the plant. The results revealed the presence of 17 compounds. The fatty acids, linoleic acid and palmitic acid, were the most abundant phyto-constituents identified from the $n$-hexane subfraction. Linoleic acid was much more predominant than palmitic acid. It is suggested that linoleic acid, and to a lesser extent, palmitic acid, could have some roles to play in the antimalarial activity of the plant. Other lesser constituents such as oleic acid, stearic acid and the esters of fatty acid could also have some effect in the overall activity of the plant. Linoleic acid is an 18-carbon polyunsaturated omega- 6 fatty acid, often denoted as 18:2 (n-6) or $18: 2$ cis- 9,12 . It is one of the two essential fatty acids (the other being a-linolenic acid). Palmitic acid is a 16-carbon saturated fatty acid commonly found in living organisms. Fatty acids, particularly polyunsaturated fatty acids (PUFA), and diets rich in fats have been demonstrated to exhibit remarkable antimalarial property in a number of studies [21-23]. Thus, in the present study, it is possible that the linoleic acid acts in synergy with palmitic acid and the other identified constituents to exert the antimalarial effect.

Another interesting observation in the present study is that lower doses of the plant extract (100 and $200 \mathrm{mg} / \mathrm{kg}$ ) produced better effect than the higher dose of $400 \mathrm{mg} / \mathrm{kg}$. When the extract was purified and the fractions administered at a dose of $200 \mathrm{mg} / \mathrm{kg}$, the effect became more pronounced. This suggests the presence of some metabolites that possibly antagonized the antimalarial activity of the plant at higher doses. One possible explanation is that the presence of antioxidants such as vitamin C, carotenoids and phenolic compounds in A. comosus [24] could have attenuated its antimalarial activity. Antioxidants were reported to have antagonistic action against parasite-killing by fatty acids when both are administered together [25]. Thus, the extract at higher dose of $400 \mathrm{mg} / \mathrm{kg}$, could contain higher concentration of antioxidants that possibly antagonized the antimalarial action of the plant leading to lower activity.

In summary, fatty acids could play some role in the antimalarial activity of $A$. comosus. However, the actual roles of fatty acid in the activity of this plant and the mode of action need further investigation. Other fractions could also be investigated to determine the actual antimalarial constituents of the plant. It is possible that the antimalarial constituents of the plant are diverse in nature.

\section{CONCLUSION}

The present study shows that $A$. comosus peel has antimalarial property. The finding supports the folkloric use of the plant for the treatment of malaria. The data from the present study also revealed the abundance of fatty acids, linoleic acid and palmitic acid, which could play some roles in the bioactivity of the plant. Further studies aimed at isolation the active principle of $A$. comosus and investigating the mode of action are recommended. 


\section{DECLARATIONS}

\section{Acknowledgement}

The authors are grateful to Mr. Felix Nwafor for identifying the plant. They are also grateful to Zikora Uzor for providing some technical assistance.

\section{Conflict of interest}

No conflict of interest is associated with this work.

\section{Contribution of authors}

The authors declare that this work was done by the authors named in this article and all liabilities pertaining to claims relating to the content of this article will be borne by them. All authors contributed in the design, laboratory studies and analysis of the data. The first draft of the manuscript was written by PFU. All authors approved the final draft of the manuscript.

\section{Open Access}

This is an Open Access article that uses a funding model which does not charge readers or their institutions for access and distributed under the terms of the Creative Commons Attribution License (http://creativecommons.org/licenses/by/ 4.0) and the Budapest Open Access Initiative (http://www.budapestopenaccessinitiative.org/rea d), which permit unrestricted use, distribution, and reproduction in any medium, provided the original work is properly credited.

\section{REFERENCES}

1. Asnaashari S, Afshar FH, Ebrahimi A, Moghadam SB, Delazar $A$. In vitro antimalarial activity of different extracts of Eremostachys macrophylla Montbr. \& Auch. Biolmpacts 2015; 5(3): 135-140.

2. Fairhurst RM, Dondorp AM. Artemisinin-resistant Plasmodium falciparum malaria. Microbiol Spectr 2016; 4(3): 1-25.

3. Ma J, Kanakala $S$, He $Y$, Zhang J, Zhong $X$. Transcriptome sequence analysis of an ornamental plant, Ananas comosus var. bracteatus, revealed the potential unigenes involved in terpenoid and phenylpropanoid biosynthesis. PLOS ONE 2015; 10(3): e0119153. doi:10.1371/journal.pone.0119153

4. Li T, Shen P, Liu W, Liu C, Liang R, Yan N, Chen J. Major polyphenolics in pineapple peels and their antioxidant interactions. Int J Food Prop 2014; 17(8): 1805-1817.
5. Ogawa EM, Costa HB, Ventura JA, Caetano L, Pinto PE, Oliveira BG, Barroso MES, Scherer R, Endringer DC, Romão W. Chemical profile of pineapple cv. Vitória in different maturation stages using electrospray ionization mass spectrometry. J Sci Food Agric 2018; 98(3): 11051116.

6. Hossain MF, Akhtar S, Anwar M. Nutritional value and medicinal benefits of pineapple. Int $J$ Nutr Food Sci 2015; 4(1): 84-88.

7. Yetein MH, Houessou LG, Lougbe'gnon TO, Teka O, Tente B. Ethnobotanical study of medicinal plants used for the treatment of malaria in plateau of Allada, Benin (West Africa). J Ethnopharmacol 2013; 146: 154-163.

8. Saotoing $P$, Vroumsia $T$, Tchobsala, Fernand-N TF, Alexandre-Michel NN, Jean M. Medicinal plants used in traditional treatment of malaria in Cameroon. J Ecol Nat Environ 2011; 3: 104-117.

9. Aiyeloja $A A$, Bello $O A$. Ethnobotanical potentials of common herbs in Nigeria: A case study of Enugu state. Educ Res Rev 2006; 1(1): 16-22.

10. Iyamah PC, Idu M. Ethnomedicinal survey of plants used in the treatment of malaria in Southern Nigeria. $J$ Ethnopharmacol 2015; 73: 287-302.

11. Omosun GI, Okoro IA, Ekundayo E, Ojimelukwe PC, Ibe Ol. Ethnobotanical study of medicinal plants useful for malaria therapy in eight local government areas of Abia State, Southeast Nigeria. Advanc Med Plant Res 2013; 1(2): 39-44.

12. Okokon JE, Okokon PJ, Sahal D. In vitro antiplasmodial activity of some medicinal plants from Nigeria. Int $J$ Herb Med 2017; 5(5): 102-109.

13. National Research Council. Guide for the care and use of laboratory animals. National Academies Press; 2010.

14. Ryley JF, Peters W. The antimalarial activity of some quinoline esters. Ann Trop Med Parasitol 1995; 84: 209222.

15. Bantie L, Assefa S, Teklehaimanot T, Engidawork E. In vivo antimalarial activity of the crude leaf extract and solvent fractions of Croton macrostachyus Hocsht. (Euphorbiaceae) against Plasmodium berghei in mice. BMC Compl Altern Med 2014; 14:79, doi: 10.1186/14726882-14-79.

16. Bhatnagar M, Avasthi AS, Singh S, Ghosal S. Evaluation of anti-leishmanial and antibacterial activity of Waldheimia tomentosa (Asteraceae), and chemical profiling of the most bioactive fraction. Trop $J$ Pharm Res 2017; 16(9): 2169-2178.

17. Birru EM, Geta M, Gurmu AE. Antiplasmodial activity of Indigofera spicata root extract against Plasmodium berghei infection in mice. Malaria J 2017; 16:198.

18. Adugna M, Feyera T, Taddese W, Admasu P. In vivo antimalarial activity of crude extract of aerial part of Artemisia abyssinica against Plasmodium berghei in mice. Global J Pharmacol 2014; 8: 460-468.

19. Trigg PI, Kondrachine AV. The current global malaria situation. In: Sherman IW, editor. Malaria parasite biology, pathogenesis, and protection. Washington DC: ASM Press; 1998. p. 11-22.

Trop J Pharm Res, January 2020; 19(1): 144 
20. Deharo E, Bourdy G, Quenevo C, Munoz V, Ruiz G, Sauvain M. A search for natural bioactive compounds in Bolivia through a multidisciplinary approach. Part V. Evaluation of the antimalarial activity of plants used by the Tacana Indians. J Ethnopharmacol 2001; 77: 9198.

21. Kumaratilake LM, Robinson BS, Ferrante A, Poulost $A$. Antimalarial properties of $n-3$ and $n-6$ polyunsaturated fatty acids: in vitro effects on Plasmodium falciparum and in vivo effects on P. berghei. J Clin Investig 1992; 89: 961-967.

22. Lutgen $P$. New insights into malaria prophylaxis. Pharm Pharmacol Int J 2017; 5(6):00141.
23. Lutgen $P$. The strong prophylactic and antimalarial properties of polyunsaturated fatty acids, 2016 [cited 2019 December 11]. Available from: https://malariaworld.org/blog/strong-prophylactic-andantimalarial-properties-polyunsaturated-fatty-acids.

24. Ferreira EA, Siqueira HE, Boas EVV, Hermes VS, Rios $A D O$. Bioactive compounds and antioxidant activity of pineapple fruit of different cultivars. Rev Bras Frutic 2016; 38(3): e-146.

25. Zuzarte-Luís V, Mello-Vieira J, Marreiros IM, Liehl $P$, Chora AF, Carret CK, Carvalho T, Mota MM. Dietary alterations modulate susceptibility to Plasmodium infection. Nature Microbiol 2017; 2: 1600-1607. 